\title{
Antioxidant and Glucose Lowering Effects of Hydroethanolic Extract of Baillonella toxisperma Pulp
}

\author{
Takuisssu Nguemto Guy Roussel ${ }^{1}$, Ngondi Judith Laure ${ }^{1} \&$ Oben Julius Enyong ${ }^{1}$ \\ ${ }^{1}$ Department of Biochemistry, Faculty of Science, University of Yaounde 1, Yaounde, Cameroon \\ Correspondence: Ngondi Judith Laure, Department of Biochemistry, Faculty of Science, University of Yaounde \\ 1, Yaounde, Cameroon. E-mail: ngondijudithl@ hotmail.com
}

Received: October 6, 2019

Accepted: February 4, $2020 \quad$ Online Published: March 1, 2020

doi:10.5539/jfr.v9n2p20

URL: https://doi.org/10.5539/jfr.v9n2p20

\begin{abstract}
Hyperglycemia and oxidative stress play an important role in the pathogenesis of diabetes. Their management is a key point in the prevention and treatment of this disease which is a potential cause of mortality in the world. We evaluated the antioxidant and glucose lowering effects of hydroethanolic extract of Baillonella toxisperma pulp. The total polyphenol and flavonoid contents were determined and the antioxidant activity was evaluated by 3 mechanisms: scavenging by DPPH•, ABTS• and $\mathrm{NO} \cdot$ radicals; reducing property by $\mathrm{MoO}_{4}{ }^{2+}$ and $\mathrm{Fe}^{3+}$ reduction; metal chelation by $\mathrm{Cu}^{2+}$ and $\mathrm{Fe}^{2+}$. Glucose adsorption capacity was evaluated followed by the capacity to promote insulino-sensitivity through glucose uptake by yeast and muscle cell assays. The hydroethanolic extract of B. toxisperma pulp possessed high total polyphenols and flavonoids; $459.55 \mu \mathrm{g}$ Equivalent Gallic $\mathrm{Acid} / \mathrm{mg}$ and $252.15 \mu \mathrm{g}$ of Equivalent Catechin $/ \mathrm{mg}$ respectively. This showed their ability to scavenge DPPH•, ABTS• and NO radicals with $\mathrm{SC}_{50}$ of $3.49,3.24$ and $4.28 \mathrm{mg} / \mathrm{ml}$ respectively. The extract also reduced $\mathrm{MoO}_{4}{ }^{2+}$ and $\mathrm{Fe}^{3+}$ and chelated $\mathrm{Cu}^{2+}$ through inhibiting their capacity to induce hemolysis with the $\mathrm{IC}_{50}$ of $3.49 \mathrm{mg} / \mathrm{ml}$. The extract showed a high glucose binding capacity with a glucose binding percentage rise of $60 \%$. It increased yeast cell absorption of glucose with the increasing percentage varying from 42.97 to $56.62 \%$. In the muscle cells, after $30 \mathrm{~min}$ of administration of the extract, we also noted an increased glucose absorption with the percentage glucose reducing to $22 \%$. We demonstrated that hydroethanolic extract of $B$. toxisperma pulp possess antiradical, reducing, metal chelating, glucose binding and insulino-sensitivity promoting properties. These mechanisms imply that $B$. toxisperma pulp is both a good antioxidant and an antihyperglycemiant, thus a potential agent in the management of diabetes and its complications.
\end{abstract}

Keywords: B. toxisperma pulp, polyphenols, antioxidant and glucose lowering effects, and diabetes

\section{Introduction}

Diabetes is a metabolic disorder of carbohydrate, lipid and protein, characterized by chronic hyperglycemia resulting from a defect in the action and/or secretion of insulin. Insulin defects are responsible for the decrease in glucose uptake that leads to intracellular hypoglycemia and extracellular hyperglycemia (Asmat, Abad \& Ismail, 2016). The long-term effect of hyperglycemia in diabetes, through mechanisms such as protein glycation, the polyol and protein kinase C pathways is oxidative stress (Tangvarasittichai, 2015). Oxidative stress is characterized by the excessive production of free radicals. When produced at low doses, oxidative species play a physiological role in the human body. However, excessive production causes cellular damage, disrupting certain signaling pathways (Brand, 2016; Sies, 2015) due to the deleterious effects of free radicals on proteins, lipids and nucleic acids, oxidative stress is strongly implicated in the establishment and progression of type 2 diabetes mellitus (Ayepola, Brooks \& Oguntibeju, 2014).

In view of the involvement of hyperglycemia and oxidative stress in the development of type 2 diabetes mellitus, its effective management requires a focus on these two metabolic disorders. Major antihyperglycemic mechanisms are: inhibition of digestion and absorption of dietary carbohydrates, inhibition of endogenous glucose production and glucose uptake by stimulation of insulin sensitivity (Agnaniet et al., 2016) while antioxidant mechanisms include: free radical scavenging, metal reduction and chelation (Meenatchi \& Jeyaprakash, 2015). Through these mechanisms, numerous synthetic antihyperglycemic agents have emerged, like metformin and Vitamin E. However, synthetic compounds are associated with many side effects (hypoglycemia, gastrointestinal disorders, liver lesions) (American Diabetes Association, 2017); and despite 
their heavy presence in the pharmaceutical market, diabetes continues to spread. There is therefore need to accentuate research towards new and safer molecules. Plants are important sources of bioactive molecules, which are distributed among the different parts and essentially in the fruits where one finds considerable contents of polyphenols, endowed with few side effects notably for the edible parts. The plethora of fruits in polyphenols and especially flavonoids makes them potentially useful in the effective management of diabetes (Aslam $e t$ al., 2007, Rauter et al., 2009).

Baillonella toxisperma is a plant of the Sapotaceae family whose fruits are edible and its wood and oil exploited for commercial purposes (Doucet \& Kouadio, 2007). Its bark is traditionally used to treat abscesses, stomach disorder, infertility in men and women, rheumatism, convulsions and malaria (Ntié-Kang et al., 2013). Fungo et al. (2015) showed that the content of polyphenols, flavonoids and proanthocyanates in the fruit of B. toxisperma was $686.7,141.1$ and $28 \mu \mathrm{g} / \mathrm{mg}$ dry matter respectively. The aim of this study was to evaluate the in vitro antioxidant and antidiabetic properties of hydroethanolic extracts of Baillonella toxisperma edible fruits.

\section{Methods}

\subsection{Chemicals}

All the chemicals used were of analytical grade and were purchased from Sigma Co., Louis, MO, USA.

\subsection{Plant Material}

Fruits of Baillonella toxisperma were harvested in Ondodo (East-Cameroon). They were identified at national herbarium. After drying in an oven at $50^{\circ} \mathrm{C}$ for 3 days, the pulp was separated from the kernel. The dried material was ground to obtain powder, from which their extracts were prepared.

\subsection{Preparation of Extracts}

The pulp (100g) was ground and extracted by maceration for $48 \mathrm{~h}$ with $800 \mathrm{ml}$ of hydroethanol $(1: 1, \mathrm{v} / \mathrm{v})$. The resulting supernatant was filtered using Whatman \#1 filter paper (Whatman International Limited, Kent, England) in a funnel and concentrated to about $10 \%$ of the original volume by a rotavapor before drying in an oven at $50^{\circ} \mathrm{C}$. The hydroethanolic extract was obtained and stored in desiccators.

\subsection{Quantitative Determination of Polyphenolic Compounds}

The quantitative analysis of total polyphenols and flavonoids was done.

\subsubsection{Determination of Total Polyphenol content}

The polyphenol content was evaluated using the method described by Singleton \& Rossi (1965). To $30 \mu \mathrm{L}$ of extract $(1 \mathrm{mg} / \mathrm{mL})$ prepared in ethanol solution, $1 \mathrm{~mL}$ of Folin Ciocalteu $(0.2 \mathrm{~N})$ solution was added. Thirty minutes after incubation at $25^{\circ} \mathrm{C}$, the absorbance was read at $750 \mathrm{~nm}$ using a spectrophotometer. Gallic acid was used as standard. The total polyphenol content was expressed in microgram equivalence of gallic acid/g of extract.

\subsubsection{Determination of Flavonoid Content}

The flavonoid content was evaluated using the method described by Aiyegoro \& Okoh (2010). To $1 \mathrm{~mL}$ of the extract $(1 \mathrm{mg} / \mathrm{mL}), 1 \mathrm{~mL}$ of aluminium chloride $(10 \%), 1 \mathrm{~mL}$ of potassium acetate $(1 \mathrm{M})$ and $5.6 \mathrm{~mL}$ of distilled water were added. The mixture was allowed to stand at $25^{\circ} \mathrm{C}$ for 30 minutes. The absorbance of the reaction mixture was read at $420 \mathrm{~nm}$ with a spectrophotometer. Catechin was used as the standard. The flavonoid content was expressed in milligram equivalence of catechin/g of extract.

\subsection{Antioxidant Potential}

The antioxidant potential of the extract was evaluated through 3 mechanisms: radical scavenging, reducing properties and metal chelation.

\subsubsection{Radical Scavenging}

For the scavenging activity, 2 synthetic radicals (DPPH and ABTS) and one biological radical (NO) were used.

\section{DPPH free-radical scavenging assay}

The antioxidant activity of the extract $(1 ; 2 ; 3 ; 4$ and $5 \mathrm{mg} / \mathrm{ml})$ prepared in ethanol solution was measured in terms of radical scavenging ability, according to the DPPH method (Katalinié, Milos, Musi \& Boban, 2004). A volume of $50 \mu \mathrm{l}$ of extract was introduced into $1.95 \mathrm{ml}$ of a methanolic solution of DPPH $(0.3 \mathrm{mM})$ and kept in the dark for $30 \mathrm{~min}$. Control experiments without the extract but with equivalent amounts of methanol were conducted in a similar manner. The absorbance was then spectrophotometrically read at $517 \mathrm{~nm}$. Catechin was used as reference. 


\section{ABTS free-radical scavenging assay}

The ABTS solution was prepared by mixing $8 \mathrm{mM}$ of ABTS with $3 \mathrm{mM}$ of potassium persulfate in $25 \mathrm{ml}$ of distil water. The solution was maintained at room temperature in the dark for 16 hours before use $(\operatorname{Re} e t$ al., 1999). The $\mathrm{ABTS}^{+}$solution was diluted 10 times with $95 \%$ ethanol. A volume of $20 \mu 1$ of the extract $(1 ; 2 ; 3 ; 4$ and $5 \mathrm{mg} / \mathrm{ml}$ ), was mixed with $1 \mathrm{~mL}$ of diluted $\mathrm{ABTS}^{+}$solution and incubated for $30 \mathrm{~min}$ at room temperature. Control experiments without the extract but with equivalent amounts of distil water were conducted in a similar manner. The absorbance was read at $734 \mathrm{~nm}$ after $30 \mathrm{~min}$. Catechin was used as reference.

\section{Nitric Oxide Scavenging Activity}

Nitric oxide was generated from sodium nitroprusside and measured by Griess' reaction (Green et al., 1982). Sodium nitroprusside $(2 \mathrm{ml}, 5 \mathrm{mM})$ in standard phosphate buffer saline solution $(0.025 \mathrm{M}$; pH 7.4) was incubated with $1 \mathrm{ml}$ of the extract at different concentrations $(1 ; 2 ; 3 ; 4$ and $5 \mathrm{mg} / \mathrm{ml})$ and the tubes were incubated at $25^{\circ} \mathrm{C}$ for 5 hours. Control experiments without the extract but with equivalent amounts of the buffer solution were conducted in a similar manner. After 5 hours, $0.5 \mathrm{ml}$ of each medium was removed and diluted with $0.5 \mathrm{ml}$ of Griess' reagent (1\% sulphanilamide, 2\% Orthophosphoric acid and $0.1 \%$ Naphthyl Ethylene Diamine dihydrochloride). The absorbance of the chromophore formed during diazotization of nitrite with sulphanilamide and its subsequent coupling with Naphthyl Ethylene Diamine was read at $546 \mathrm{~nm}$. Catechin was used as reference.

For the 3 radical scavenging assays, percentage inhibition was calculated according to the following equation:

Scavenging effect $(\%)=[($ Abs control - Abs sample $) /$ Abs control $] \times 100$

Scavenging Concentration $50\left(\mathrm{SC}_{50}\right)$ parameter was used for the interpretation of the results (Brand-Williams et al., 1996). The discoloration of the sample was plotted against its concentration in order to calculate the $\mathrm{SC}_{50}$ value. It is defined as the amount of sample necessary to decrease the absorbance of the radical solution by $50 \%$.

\subsubsection{Reducing Property}

This activity was evaluated through the ability of the extract to reduce the $\mathrm{MoO}_{4}{ }^{2-}$ and $\mathrm{Fe}^{3+}$.

\section{Phosphomolybdenum method}

The assay is based on the reduction of Mo (VI) to Mo (V) by the sample analyte and subsequent formation of a green phosphate Mo (V) complex at acidic $\mathrm{pH}$. Total antioxidant capacity can be calculated following the method described by Prieto, Pineda \& Aguilar (1999). A volume of $0.1 \mathrm{~mL}$ of extract $(5 ; 6.25 ; 7.5 ; 8.75$ and 10 $\mathrm{mg} / \mathrm{ml})$ solution was combined with $1 \mathrm{~mL}$ of reagent $(0.6 \mathrm{M}$ sulfuric acid, $28 \mathrm{mM}$ sodium phosphate and $4 \mathrm{mM}$ ammonium molybdate). The tube was capped and incubated in a boiling water bath at $95{ }^{\circ} \mathrm{C}$ for $90 \mathrm{~min}$. After cooling the sample to room temperature, the absorbance of the aqueous solution was measured at $695 \mathrm{~nm}$. A typical blank solution contained $1 \mathrm{~mL}$ of reagent solution and the appropriate volume of the same solvent used for the sample and it was incubated under the same conditions as the rest of the sample. Catechin was used as reference and Trolox as the standard. The results were expressed as total antioxidant capacity in milligram equivalence of trolox/mg of extract.

\section{Reducing power method}

The assay was determined by assessing the ability of the extract to reduce $\mathrm{Fe}^{3+}$ to $\mathrm{Fe}^{2+}$ as described by Oyaizu (1986). A volume of $2.5 \mathrm{~mL}$ of extract $(1 \mathrm{mg} / \mathrm{ml})$ was mixed with $2.5 \mathrm{~mL}$ of sodium phosphate buffer ( $\mathrm{pH} 6.6$; $200 \mathrm{mM}$ ) and $2.5 \mathrm{~mL}$ of potassium ferricyanide $(1 \%)$. The mixture was incubated at $50^{\circ} \mathrm{C}$ for $20 \mathrm{~min}$ and then $2.5 \mathrm{~mL}$ of trichloroacetic acid (10\%) was added. This mixture was centrifuged at $650 \mathrm{rpm}$ for $10 \mathrm{~min} .5 \mathrm{~mL}$ of the supernatant was mixed with an equal volume of water and $1 \mathrm{~mL}$ of ferric chloride $(0.1 \%)$. Control experiments without the test compounds but equivalent amounts of distil water were conducted in identical manner. The absorbance was measured at $700 \mathrm{~nm}$. Catechin was used as reference.

The results were expressed as percentages of reducing iron:

$\mathrm{Fe}^{3+}$ Reducing $(\%)=[($ Abs control - Abs sample $) /$ Abs control $] \times 100$

\subsubsection{Metal Chelation}

This activity was evaluated using the $\mathrm{Cu}^{2+}$ chelating through the hemolysis assay.

\section{Hemolysis assay}

The assay was done following the method of Arbos, Ligia, Lucielly, Cid \& Almeriane (2008). Blood was collected by venepuncture from wistar male rat $(150 \mathrm{~g})$ in heparinized tubes and centrifuged at 3,000 $\mathrm{g}$ for 15 
min. Plasma and buffy coat were removed. Red blood cells (RBCs) were suspended in 10 volumes of $\mathrm{NaCl}$ $(0.9 \%)$ and centrifuged at 2,500 rpm for $5 \mathrm{~min}$. The RBCs were washed three times with the same solution. During the last washing, the packed cells were resuspended in 10 volumes of $\mathrm{NaCl}(0.9 \%)$ and utilized for the following assay. The effect of the extract on ferrous ion-induced haemolysis was evaluated. A volume of $0.2 \mathrm{ml}$ of the extract $(5 ; 6.25 ; 7.5 ; 8.75$ and $10 \mathrm{mg} / \mathrm{ml})$ was mixed with $1 \mathrm{~mL}$ of $\mathrm{NaCl}(0.9 \%)$ and $0.1 \mathrm{ml}$ of RBC suspension and incubated at $37^{\circ} \mathrm{C}$ for $30 \mathrm{~min}$. After incubation, $0.1 \mathrm{~mL}$ of $\mathrm{CuSO}_{4}(0.1 \mathrm{M})$ was added and further incubated at $37^{\circ} \mathrm{C}$ for $30 \mathrm{~min}$. Haemolysis was determined by measuring absorbance of the supernatant at 540 $\mathrm{nm}$. The reaction without the extract was used as control. Catechin was used as reference.

Percentage of haemolysis inhibition was calculated using the equation:

Percentage Inhibition $(\%)=[($ Abs control - Abs sample $) /$ Abs control $] \times 100$

Inhibition Concentration $\left(\mathrm{IC}_{50}\right)$ parameter was used for the interpretation of the results.

\subsection{Glucose Lowering Effect}

The glucose lowering effect of the extract was evaluated through 2 mechanisms: glucophagic property through the glucose adsorption assay and insulino-sensitivity stimulating effects through glucose uptake by yeast and muscle cell assays.

\subsubsection{Glucose Adsorption Capacity}

Glucose adsorption capacity of the extract was determined according to the method of Ou, Kwok, $\mathrm{Li} \& \mathrm{Fu}$ (2001). Briefly, $1 \mathrm{ml}$ of extract at different concentrations $(5 ; 10 ; 15$ and $20 \mathrm{mg} / \mathrm{ml}$ ) was added to $1 \mathrm{~mL}$ of glucose solution of increasing concentration $(12.5,25,37.5$ and $50 \mathrm{mM})$, the mixture was well stirred, incubated in a shaking water bath at $37{ }^{\circ} \mathrm{C}$ for $1 \mathrm{hr}$, centrifuged at $4,000 \mathrm{~g}$ for $20 \mathrm{~min}$ and the glucose content in the supernatant was determined according to the method of Trinder (1959). Bound glucose was calculated using the following formula.

Percentage bound glucose $(\%)=\left[\left(\right.\right.$ Glucose $_{\text {initial }}-$ Glucose $\left._{\text {final }}\right) /$ Glucose $\left._{\text {initial }}\right] \times 100$

\subsubsection{Glucose Uptake by Yeast Cells}

Yeast cells were prepared according to the method of Cirillo (1962). Commercial baker's yeast was washed by repeated centrifugation $(4,000 \mathrm{~g}$ for 5 minutes) in distilled water until the supernatant was clear and a $10 \%(\mathrm{v} / \mathrm{v})$ suspension prepared in distilled water. Various concentrations of extracts $(2.5 ; 5 ; 7.5$ and $10 \mathrm{mg} / \mathrm{ml})$ were added to $1 \mathrm{~mL}$ of glucose solution $(25 \mathrm{mmol} / \mathrm{L})$ and incubated for 10 minutes at $37^{\circ} \mathrm{C}$. The reaction was started by adding $100 \mu \mathrm{L}$ of yeast suspension, vortexed, and further incubated at $37^{\circ} \mathrm{C}$ for 60 minutes. After 60 minutes, the tubes were centrifuged (3,000 $\mathrm{g}$ for 5 minutes) and glucose in the supernatant was determined according to the method of Trinder (1959). The reaction without the extract was used as control. The percentage increase in glucose uptake by yeast cells was calculated using the following formula.

Percentage increasein glucose uptake $(\%)=[($ Abs control - Abs sample $) /$ Abs control $] \times 100$

\subsubsection{Glucose Uptake in Rat Psoas Muscle Tissue}

Glucose uptake in rat psoas muscle tissue of the extract was determined according to the method of Al-Awadi, Khattar, \& Gumma. (1985). Psoas muscle was isolated from two anaesthetized adult rats and placed immediately in Krebs solution containing glucose $(11.1 \mathrm{mM})$. Muscle tissue was cut into pieces of equal mass, about $0.25 \mathrm{~g}$, and preincubated for $5 \mathrm{~min}$ in $\mathrm{CO}_{2}$ incubator as mentioned above. Triple sets including muscle tissue alone (Control), muscle tissue with insulin $(50 \mathrm{mU} / \mathrm{l})$, muscle tissue with both insulin and extract $(5,7.5 \mathrm{and} 10 \mathrm{mg} / \mathrm{ml})$ were incubated for $2.5 \mathrm{hrs}$ in $\mathrm{CO}_{2}$ incubator under $95 \% \mathrm{O}_{2}$ and $5 \% \mathrm{CO}_{2}$ atmosphere. Aliquots of $2 \mathrm{ml}$ were removed from incubation mixture at 0,30 and $60 \mathrm{~min}$, and changes in glucose concentration were measured according to the method of Trinder (1959). Percent glucose uptake was calculated using the following formula.

Glucose uptake $(\%)=[($ Abs control - Abs sample $) /$ Abs control $] \times 100$

\subsection{Statistical Analysis}

All experiments were performed in triplicate. The statistical package of social sciences (SPSS) software version 20.0 (Chicago-Illinois Inc.) was used and Tukey's test was performed to compare variability amongst the groups. One-way analysis of variance (anova) significant differences were detected at $95 \%$ confidence interval. The results obtained were expressed as mean $\pm \mathrm{SD}$ from three distinct observations. The $\mathrm{IC}_{50}$ and $\mathrm{SC}_{50}$ values were calculated by linear regression and Microsoft Excel was used for graphical depiction. 


\section{Results}

\subsection{Polyphenolic Compound Content}

The polyphenol content of hydroethanolic extract of B. toxisperma pulp is shown in table 1. Polyphenols and flavonoids were indicated at $459.55 \mu \mathrm{g}$ GAE$/ \mathrm{mg}$ and $252.15 \mu \mathrm{g} \mathrm{EC} / \mathrm{mg}$ respectively.

Table 1. Phytochemical content of extract

\begin{tabular}{lll}
\hline Extract & $\begin{array}{l}\text { Polyphenols } \\
(\mu \mathrm{g} \mathrm{GA} / \mathrm{mg} \text { of extract })\end{array}$ & $\begin{array}{l}\text { Flavonoids } \\
(\mu \mathrm{g} \mathrm{CE} / \mathrm{mg} \text { of extract })\end{array}$ \\
\hline Hydroethanolic Extract of B. toxisperma pulp & $459.55 \pm 3.79$ & $252.15 \pm 1.57$ \\
\hline
\end{tabular}

GAE: Gallic Acid Equivalence ; CE: Catechin Equivalence.

\subsection{Radical Scavenging activity}

The $\mathrm{SC}_{50}$ of hydroethanolic extract of $B$. toxisperma pulp are presented in table 2 . The extract showed scavenging activity on $\mathrm{DPPH} \bullet \mathrm{ABTS} \bullet$ and $\mathrm{NO} \bullet$ radicals. The $\mathrm{SC}_{50}$ were 3.24, 3.49 and 4.28 respectively for ABTS•, DPPH• and NO radicals. The extract showed a lower $\mathrm{DPPH} \bullet$, ABTS $\bullet$ and NO scavenging activity than Catechin.

Table 2. Scavenging activities of extract

\begin{tabular}{llll}
\hline $\mathrm{EC}_{50}$ of radicals & $\mathrm{SC}_{50} \mathrm{DPPH}(\mathrm{mg} / \mathrm{ml})$ & $\mathrm{SC}_{50} \mathrm{ABTS}(\mathrm{mg} / \mathrm{ml})$ & $\mathrm{SC}_{50} \mathrm{NO}(\mathrm{mg} / \mathrm{ml})$ \\
\hline Hydroethanolic Extract of $B$. toxisperma pulp & $3.49^{*}$ & $3.24^{*}$ & $4.28^{*}$ \\
Catechin & 1.45 & 1.54 & 1.25 \\
\hline
\end{tabular}

$\mathrm{SC}_{50}$ : $50 \%$ Scavenging Concentration, $* \mathrm{p}<0.05$ : significantly different in comparison to catechin.

\subsection{Reducing Property}

The ability of the extract to reduce $\mathrm{MoO}_{4}{ }^{2-}$ and $\mathrm{Fe}^{3+}$ ions is shown in table 3 .

The $\mathrm{MoO}_{4}{ }^{2-}$ reducing capacity is expressed as total antioxidant capacity (TAC). The extract TAC was proportional to its concentration. TAC varied from 2.09 to $3.51 \mathrm{mg} \mathrm{TE} / \mathrm{mg}$.

The $\mathrm{Fe}^{3+}$ reducing capacity is expressed as percentage of reduced ferric ions. The extract reduced $\mathrm{Fe}^{3+}$ with a reducing percentage of $15.31 \%$.

The extract showed the $\mathrm{Fe}^{3+}$ reducing capacity was lower than that of catechin.

Table 3. Reducing property of extract

\begin{tabular}{|c|c|c|c|c|c|c|}
\hline Assays & Total Anti & xidant Cap & y $\mathrm{mg} \mathrm{ET/g}$ & f sample & & $\begin{array}{ll}\mathrm{Fe}^{3+} & \text { Reducing } \\
(\%) & \end{array}$ \\
\hline [Sample] & $5 \mathrm{mg} / \mathrm{ml}$ & $\begin{array}{l}6.25 \\
\mathrm{mg} / \mathrm{ml}\end{array}$ & $7.5 \mathrm{mg} / \mathrm{ml}$ & $\begin{array}{l}8.75 \\
\mathrm{mg} / \mathrm{ml}\end{array}$ & $10 \mathrm{mg} / \mathrm{ml}$ & $1 \mathrm{mg} / \mathrm{ml}$ \\
\hline $\begin{array}{l}\mathrm{HE} \text { of } B . \text { toxisperma } \\
\text { pulp }\end{array}$ & $2.09 \pm 0.02$ & $2.5 \pm 0.05$ & $3.07 \pm 0.01$ & $3.39 \pm 0.07$ & $3.51 \pm 0.01$ & $31.02 \pm 1.6 *$ \\
\hline Catechin & & & & & & $51.09 \pm 2.2$ \\
\hline
\end{tabular}

HE: Hydroethanolic Extract; TE: Trolox Equivalence.

\subsection{Metal Chelation}

The ability of the extract to inhibit haemolysis by chelating $\mathrm{Cu}^{2+}$ is shown in table 4 . The extract showed inhibitory activity on haemolysis with $\mathrm{IC}_{50}$ of $3.49 \mathrm{mg} / \mathrm{ml}$. The extract showed a lower activity than catechin.

Table 4. $\mathrm{IC}_{50}$ of extract on hemolysis

\begin{tabular}{ll}
\hline & $\mathrm{IC}_{50}$ Hemolysis $(\mathrm{mg} / \mathrm{ml})$ \\
\hline HE of $B$. toxisperma pulp & $3.49^{*}$ \\
Catechin & 2.3 \\
\hline
\end{tabular}

HE: Hydroethanolic Extract; IC: Inhibitory Concentrations. ${ }^{*} \mathrm{p}<0.05$ : significantly different in comparison to catechin. 


\subsection{Glucose Binding Capacity}

The glucose binding capacity of the extract was evaluated through the glucose adsorption capacity and is shown in figure 1 . The extract could bind glucose effectively, and the glucose binding capacity was directly proportional to the extract and glucose concentrations. The extract was effective in adsorbing glucose at both lower and higher concentrations. The percentages of glucose binding rise to $30.92,40,51$ and $60 \%$ respectively at extract concentrations of $5,10,15$ and $20 \mathrm{mg} / \mathrm{ml}$. The activity tended to stabilize at glucose concentrations up to 37.5 $\mathrm{mM}$.

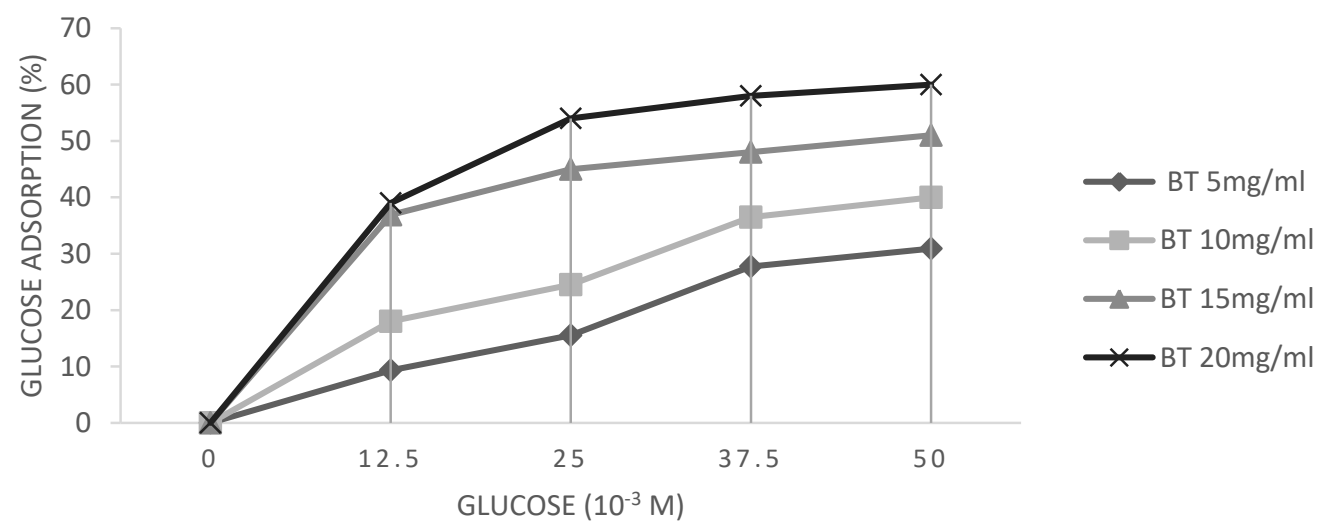

BT: B. toxisperma

Figure 1. Glucose binding capacity of extract

\subsection{Insulino-sensitivity Stimulating Properties}

The insulino-sensitivity stimulating properties of the extract was evaluated through glucose uptake by yeast cells as shown in table 5 and by muscles tissues as shown in table 6 .

The extract promoted glucose uptake by yeast cells in a manner proportional to their concentrations. The increase of glucose uptake varied from 42.97 to $56.62 \%$.

The extract also promoted the effects of insulin on glucose uptake by muscle tissues. Insulin causes a glucose uptake of $11.89 \%$ and in the presence of extract, the increase in glucose uptake was approximatively $22 \%$ in 30 min, but it decreased to approximatively $12 \%$ in $60 \mathrm{~min}$. The extract ameliorated glucose uptake in the presence of insulin to approximatively $10 \%$.

Table 5. Increase of glucose uptake by yeast cells

HE: Hydroethanolic Extract

\begin{tabular}{lllll}
\hline HE of B. toxisperma pulp & $2.5 \mathrm{mg} / \mathrm{ml}$ & $5 \mathrm{mg} / \mathrm{ml}$ & $7.5 \mathrm{mg} / \mathrm{ml}$ & $10 \mathrm{mg} / \mathrm{ml}$ \\
\hline Increase of glucose uptake (\%) & $42.97 \pm 1.05$ & $48.62 \pm 2.54$ & $51.36 \pm 3.11$ & $56.62 \pm 1.49$ \\
\hline
\end{tabular}

Table 6. Increase of glucose uptake by muscle tissues

\begin{tabular}{llll}
\hline & \multicolumn{3}{l}{ Glucose uptake (\%) } \\
\hline Time & 0 $\mathbf{m i n}$ & $\mathbf{3 0} \mathbf{m i n}$ & $\mathbf{6 0} \mathbf{~ m i n}$ \\
\hline MT & 0 & $0^{*}$ & $0^{*}$ \\
MT + Insulin & 0 & $11.89 \pm 0.75$ & $11.82 \pm 0.07$ \\
MT + Insulin + Extract $(\mathbf{5} \mathbf{~} \mathbf{~ g / m l )}$ & 0 & $21.94 \pm 2.03 *$ & $11.95 \pm 0.76$ \\
MT + Insulin + Extract $\mathbf{7 . 5} \mathbf{~ m} / \mathbf{m l})$ & 0 & $22.06 \pm 0.89 *$ & $12.03 \pm 1.04$ \\
MT + Insulin + Extract $(\mathbf{1 0} \mathbf{~ m g / m l})$ & 0 & $22.39 \pm 2.69 *$ & $12.22 \pm 1.1$ \\
\hline
\end{tabular}

MT: Muscle Tissue; *p < 0.05 : significantly different in comparison to MT + Insulin.

\section{Discussion}

The objective of this study was to evaluate the antioxidant and hypoglycaemic properties of hydroethanolic extract of B. toxisperma pulp. Specifically, it systematically had to quantify the main bioactive compounds that 
can decrease or prevent oxidative stress and reduce the high glucose level. The main target compounds were polyphenols, including flavonoids (Kim, Keogh \& Clifton, 2016; Brewer, 2011). The extract had high levels of total polyphenols and flavonoids (Table 1). In the first part of this work, we evaluated the mechanisms by which these compounds exert their possible antioxidant activity: radical scavenging, reducing agent and metal chelating capacity (Liyana-Pathirana \& Shahidi, 2006).

Concerning the antiradical power, we first evaluated the effect of the extract on 2 synthetic radicals: DPPH $\bullet$ and ABTS • which was confirmed by means of a biological radical: NO•. ABTS • and DPPH• are synthetic radicals widely used to study the anti-radical potential of antioxidants (Joginder, Akansha, Pardeep, Pooja \& Surekha, 2015). On the other hand, NO• is a free radical produced in mammalian cells which intervenes in many physiological processes but once in excess in the organism, it can initiate the development of numerous pathological processes (Prety \& Surech, 2012). The extract trapped the DPPH•,.ABTS• and NO• radicals with high $\mathrm{SC}_{50}$ values (Table 2). These results can be explained by the content of polyphenols and in particular of flavonoids in the extract which, due to the redox potential of their $\mathrm{OH}$ groups, would be capable of yielding a proton and/or an electron thus trapping the ABTS - and DPPH • radicals to give the stable compounds ABTS and DPPH-H. Indeed, the low redox potential of flavonoids (FLOH) makes them thermodynamically capable of reducing free radicals $(\mathrm{R} \bullet)$ by the transfer of a hydrogen atom or of electrons from hydroxyl groups (Procházková, Bousová \& Wilhelmová, 2011). The ability of phenolic compounds to inhibit the interaction of NO• could also be noted. With oxygen generating nitrite which is a highly oxidizing species. This could account for the antiradical capacity against NO• (Parul, Kundu \& Saha, 2013).

Subsequently, the ability to yield electrons was demonstrated in the second mechanism, which consisted of evaluating the reducing power through the capacity of the extract to reduce the $\mathrm{MoO}_{4}{ }^{2-}$ and $\mathrm{Fe}^{3+}$ ions. The extract reduced phosphomolybdenum VI to phosphomolybdenum V and ferric iron to ferrous iron (Table 3). These results can still be linked to the flavonoid content of the extract as confirmed by their ability to yield electrons. Khan, Khan, Sahreen \& Ahmed (2012) had already demonstrated the ability of flavonoids to reduce phosphomolybdenum by electron transfer.

The third mechanism consisted of evaluating the metal chelating capacity of the extract, using $\mathrm{Cu}^{2+}$ and to evaluating their effects on biological processes including the oxidation of membrane lipids in general on the one hand, and on the other hand, the oxidation of lipids of the erythrocyte membrane more precisely. Our extract chelated $\mathrm{Cu}^{2+}$ thus inhibiting haemolysis respectively (Table 4). These observations could be due to the phenolic compounds contained in this extract, that chelate $\mathrm{Cu}^{2+}$, blocking the reactive oxygen species thus preventing their oxidative action on the membrane lipids of erythrocytes (Giuseppina, 2012). Indeed, flavonoids are renowned for their ability to chelate $\mathrm{Cu}^{2+}$, thus preventing lipid peroxidation (Rahal et al., 2014).

On the other hand, Djiokeng et al. (2014) already revealed the same 3 antioxidant mechanisms with the hydroethanolic extract of $B$. toxisperma bark. Numerous fruits of the same family as that of $B$. toxisperma (Sapotaceae) have also proved their radicals scavenging, reducing and metals chelating properties: Manilkara hexandra (Parikh \& Patel, 2017), Mimusops elengi (Valvi, Rathod \& Yesane, 2011).

The second part of the study focused on the antidiabetic potential of the hydroethanolic extract of B. toxisperma pulp through glucose binding ability and insulin-sensitivity stimulating properties. The extract demonstrated the ability to engulf glucose (Figure 1). This activity is attributed to the high flavonoid content. Flavonoids through condensation reactions complex with glucose molecules through hydroxyl groups forming glycosyl-flavonoids containing osidic bonds ( $\mathrm{Li}$ et al., 2014). This activity could also be attributed to the fiber content (5.41\%) of $B$. toxisperma as reported by Fungo et al. (2015). In effect, insoluble fibers are renowned for their ability to form complexes with glucose, thus rendering them unavailable, which contributes to the reduction in intestinal glucose absorption (McRonie \& McKeown, 2017). The antihyperglycemic effect was evaluated ex vivo, by studying the ability of the extract to stimulate glucose uptake, which is greatly reduced in case of insulin resistance (Anuradha, Malini \& Jyoti, 2015). The extract stimulated the transport of glucose across the yeast cell membrane (Table 5), it was also noted that 30 minutes after administration, the extract increased the insulin-mediated glucose uptake (Table 6). This would reflect the ability of polyphenols contained in the extract to stimulate cellular uptake of glucose and GLUT translocation, hence the reduction of glucose in the reaction medium. Gaikwad, Krishna \& Sandhya (2014) had previously noted the ability of polyphenols to reduce glucose uptake due to an increase in insulin sensitivity. It has also been proven in vitro that polyphenols especially flavonoids stimulate insulin-mediated glucose uptake (Ueda-Wakagi, Mukai, Fuse, Mizushina \& Ashida, 2015; Kurimoto et al., 2013). This may be due to the ability of the extract to stimulate insulin binding to its receptors at the muscle level or to increase the number of insulin receptors (Gupta, Kesari, Watal, Murthy \& Chandra, 2005). 


\section{Conclusion}

The hydroethanolic extract of B. toxisperma pulp are potent antioxidant and hypoglycemiant, acting through different mechanisms of action and may be potential tools in the control of metabolic disorders related to diabetes that represent a burden for the society, both in terms of the increasing mortality and the costs allocated healthcare.

\section{Competing interests}

The authors declare that they have no competing interests.

\section{Authors' contributions}

TNGR carried out the study and wrote the manuscript; NJL contributed to conception, design and analysis of data, and OJE assisted with and supervised the manuscript writing. All authors have read and approved the final manuscript.

\section{References}

American Diabetes Association. (2017). Standards of Medical Care in Diabetes-2017. Diabetes Care, 40(1), 1-80. https://doi.org/10.2337/dc17-er07c

Agnaniet, H., Mbot, E., Keita, O., Fehrentz, J.-A., Ankli, A., Gallud, A., \& Menut, C. (2016). Antidiabetic potential of two medicinal plants used in Gabonese folk medicine. BMC Complementary and Alternative Medicine, 16, 71. http://dx.doi.org/10.1186/s12906-016-1052-x

Aiyegoro, O., \& Okoh, I. (2010). Preliminary phytochemical screening and in vitro antioxidant activities of the aqueous extract of Helichrysum longifolium. BMC Complement Alternative Medicine, 10, 21. http://dx.doi.org/10.1186/1472-6882-10-21

Al-Awadi, F., Khattar, M., \& Gumma, K. (1985). On the mechanism of the hypoglycemic effect of a plant extract. Diabetologia, 28, 432-434. https://doi.org/10.1007/BF00280886

Anuradha, G., Malini, S., \& Jyoti, S. (2015). A Role of Insulin in different types of Diabetes. International Journal of Current Microbiology and Applied Sciences, 4(1), 58-77.

Arbos, K., Ligia, M., Lucielly, B., Cid, A., \& Almeriane, M. (2008). Human erythrocytes as a system for evaluating the antioxidant capacity of vegetable extracts. Nutrition Research, 28, 457-463. http://dx.doi.org/10.1016/j.nutres.2008.04.004

Asmat, U., Abad, K., \& Ismail, K. (2016). Diabetes mellitus and oxidative stress--A concise review. Saudi Pharmaceutical Journal, 24, 547-553. http://dx.doi.org/10.1016/j.jsps.2015.03.013

Ayepola, O., Brooks, N., \& Oguntibeju, O. O. (2014). Oxidative Stress and Diabetic Complications: The Role of Antioxidant Vitamins and Flavonoids. http://dx.doi.org/10.5772/57282

Brand, M. (2016). Mitochondrial generation of superoxide and hydrogen peroxide as the source of mitochondrial redox signaling. Free Radical Biology Medecine, 100, 14-31. http://dx.doi.org/10.1016/j.freeradbiomed.2016.04.001

Brewer, M. (2011). Natural Antioxidants: Sources, Compounds, Mechanisms of Action, and Potential Applications. Comprehensive Reviews in Food Science and Food Safety, 10, 221-247. http://dx.doi.org/10.1111/j.1541-4337.2011.00156.x

Cirillo, V. (1962). Mechanism of glucose transport across the yeast cell membrane. Journal of Bacteriology, 84, 485-91. https://doi.org/10.1128/JB.84.3.485-491.1962

Djiokeng, P., Ngoumen, N., Youovop, F., Mbong, A., Ngondi, J., \& Oben, J. (2014). Neuroprotective effect of Baillonella toxisperma Pierre on the oxidative stress status in an experimental animal model of Alzheimer's disease. Journal of Advances in Biology, 5(3), 1-2.

Doucet, J., \& Kouadio, Y. (2007). Le moabi, une espèce «phare» de l'exploitation forestière en Afrique centrale. Parcs et Réserves, 62(2), 25-31.

Fungo, R., Muyonga, J., Kaaya, A., Okia, C., Julius, C., Tieguhong, J., \& Baidu-Forson, J. (2015). Nutrients and bioactive compounds content of Baillonella toxisperma, Trichoscypha abut and Pentaclethra macrophylla from Cameroon. Food Science \& Nutrition, 3(4), 292-301. http://dx.doi.org/10.1002/fsn3.217.

Kim, Y., Keogh, J., \& Clifton, P. (2016). Polyphenols and Glycemic Control. Nutrients, 8, 17. https://doi.org/10.3390/nu8010017 
Brewer, M. (2011). Natural Antioxidants: Sources, Compounds, Mechanisms of Action, and Potential Applications. Comprehensive Reviews in Food Science and Food Safety, 10, 221-247. https://doi.org/10.1111/j.1541-4337.2011.00156.x

Gaikwad, S., Krishna, G., \& Sandhya, M. (2014). Phytochemicals for Diabetes Management. Pharmaceutical Crops, 5(1), 11-28. http://dx.doi.org/10.2174/2210290601405010011

Giuseppina, B. (2012). Oxidative Stress and Lipid Peroxidation Products in Cancer Progression and Therapy. International Scholarly Research Notices: Oncology, 2012, 1-21. http://dx.doi.org/10.5402/2012/137289

Green, L., Wagner, D., Glogowski, J., Skipper, P., Wishnok, J., \& Tannenbaum, S. (1982). Analysis of nitrate and $15 \mathrm{~N}$ in biological fluids. Analytical Biochemistry, 239, 131. https://doi.org/10.1016/0003-2697(82)90118-X

Gupta, R., Kesari, A., Watal, G., Murthy, P., Chandra, R., Maithal, K., \& Tandon, V. (2005). Hypoglycaemic and antidiabetic effect of aqueous extract of leaves of Annona squamosa (L.) in experimental animal. Current Science, 88(8), 1244-1253. http://dx.doi.org/10.1016/j.jep.2005.01.048

Joginder, S., Akansha, R., Pardeep, K., \& Pooja, S. (2015). Antimicrobial and free radical scavenging activity of selective medicinal plants combination. World Journal of Pharmacy and Pharmaceutical Sciences, 4(3), $1202-1216$.

Katalinié, V., Milos, M., Musi, I., \& Boban, M. (2004). Antioxidant effectiveness of selected wines in comparison with (+)-catechin. Food Chemistry, 86, 593-600.

http://dx.doi.org/10.1016/j.foodchem.2003.10.00

Khan, R., Khan, M., Sahreen, S., \& Ahmed, M. (2012). Assessment of flavonoids contents and in vitro antioxidant activity of Launaea procumbens. Chemistry Central Journal, 6, 43. http://dx.doi.org/10.1186/1752-153X-6-43

Kim, Y., Keogh, J., \& Clifton, P. (2016). Polyphenols and Glycemic Control. Nutrients, 8, 17. http://dx.doi.org/10.3390/nu8010017

Kurimoto, Y., Shibayama, Y., Inoue, S., Soga, M., Takikawa, M., Ito, C., \& Tsuda, T. (2013). Black soybean seed coat extract ameliorates hyperglycemia and insulin sensitivity via the activation of AMP-activated protein kinase in diabetic mice. Journal of Agriculture and Food Chemistry, 61, 5558-5564. http://dx.doi.org/10.1021/jf401190y

Li, S-S., Wu, J., Chen, L-G., Du, H., Xu, Y-J., Wang, L-J., \& Wang, L-S. (2014) Biogenesis of C-Glycosyl Flavones and Profiling of Flavonoid Glycosides in Lotus (Nelumbo nucifera). PLoS ONE, 9(10), e108860. http://dx.doi.org/10.1371/journal.pone.0108860

Liyana-Pathirana, C., \& Shahidi, F. (2006). Antioxidant properties of commercial soft and hard winter wheats (Triticum aestivum L.) and their milling fractions. Journal of Sciences Food and Agriculture, 86, 477. http://dx.doi.org/10.1021/jf049320i

McRonie, J., \& McKeown, N. (2017). Understanding the Physics of Functional Fibers in the Gastrointestinal Tract: An Evidence-Based Approach to Resolving Enduring Misconceptions about Insoluble and Soluble Fiber. Journal of the Academy of Nutrition and Dietetics, 117(2), 251-264. http://dx.doi.org/10.1016/j.jand.2016.09.021

Meenatchi, S., \& Jeyaprakash, K. (2015). Screening of phytochemical and in vitro antioxidant property of N-Miracle (polyherbal formulation). World Journal of Pharmaceutical Research, 4(6), 1702-1717.

Ntie-Kang, F., Lifongo, L., Mbaze, L., Ekwelle, N., Owono, L., Megnassan, E., \& Efange, S. (2013). Cameroonian medicinal plants: a bioactivity versus ethnobotanical survey and chemotaxonomic classification. BMC Complementary and Alternative Medicine, 13, 147. http://dx.doi.org/10.1186/1472-6882-13-147

Ou, S., Kwok, K., Li, Y., \& Fu, L. (2001). In vitro study of possible role of dietary fiber in lowering postprandial serum glucose. Journal of Agriculture and Food Chemistry, 49, 1026-1029. http://dx.doi.org/10.1021/jf000574n

Oyaizu, M. (1986). Studies on products of browning reaction: Antioxidative activity of products of browning reaction prepared from glucosamine. Japanese Journal of Nutrition, 44, 307-315. http://dx.doi.org/10.5264/eiyogakuzashi.44.307

Parikh, B., \& Patel, V. (2017). Quantification of phenolic compounds and antioxidant capacity of anunderutilized Indian fruit: Rayan [Manilkara hexandra (Roxb.) Dubard]. Food Science and Human Wellness, 6, 10-19. 
http://dx.doi.org/10.1016/j.fshw.2016.11.002

Parul, R., Kundu, S., \& Saha, P. (2013). In Vitro Nitric Oxide Scavenging Activity Of Methanol Extracts Of Three Bangladeshi Medicinal Plants. Pharma Innovation, 1(12), 83-89.

Preeti, P., \& Suresh, N. (2012). In vitro Antioxidant Potential of an Herbal Preparation Containing Four Selected Medicinal Plants. Journal of Krishna Institute of Medical Sciences University, 1(2), 52-63.

Prieto, P., Pineda, M., \& Aguilar, M. (1999). Spectrophotometric quantitation of antioxidant capacity through the formation of a phosphomolybdenum complex : specific application to the determination of vitamin $\mathrm{E}$. Analytical Biochemistry, 269, 337-341. http://dx.doi.org/10.1006/abio.1999.4019

Procházková, D., Bousová, I., \& Wilhelmová, N. (2011). Antioxidant and prooxidant properties of flavonoids. Fitoterapia, 82(4), 513-23. http://dx.doi.org/10.1016/j.fitote.2011.01.018

Rahal, A., Kumar, A., Singh, V., Yadav, B., Tiwari, R., Chakraborty, S., \& Dhama, K. (2014). Oxidative Stress, Prooxidants, and Antioxidants: The Interplay. BioMed Research International, 2014, 1-19. http://dx.doi.org/10.1155/2014/761264

Rauter, A., Martins, A., Lopes, R., Ferreira, J., Serralheiro, L., Araujo, M., \& Mota-Filipe, H. (2009). Bioactivity studies and chemical profile of the antidiabetic plant Genista tenera. Journal of Ethnopharmacology, 122(2), 384-93. http://dx.doi.org/10.1016/j.jep.2008.10.011

Re, R., Pellegrini, N., Proteggente, A., Pannala, A., Yang, M., \& Rice-Evans, C. (1999). Antioxidant activity applying an improved ABTS radical cation decolourization assay. Free Radical Biology and Medicine, 26(9-10), 1231-1237. http://dx.doi.org/10.1016/S0891-5849(98)00315-3

Sies, H. (2015). Oxidative stress: a concept in redox biology and medicine. Redox Biology, 4, 180-183. http://dx.doi.org/10.1016/j.redox.2015.01.002

Singleton, V., \& Rossi, J. (1965). Colorimetric of total phenolics with phosphomolybdicphosphotungstic acid reagents. American Journal of Enology and Viticulture, 16, 144-158.

Tangvarasittichai, S. (2015). Oxidative stress, insulin resistance, dyslipidemia and type 2 diabetes mellitus. World Journal of Diabetes, 6(3), 456-480. http://dx.doi.org/10.4239/wjd.v6.i3.456

Trinder, P. (1969). Determination of blood glucose using 4-amino-phenazone as oxygen acceptor. Journal of Clinical Pathology, 22, 158-61. https://doi.org/10.1136/jcp.22.2.158

Ueda-Wakagi, M., Mukai, R., Fuse, N., Mizushina, Y., \& Ashida, H. (2015). 3-O-acyl-epicatechins increase glucose uptake activity and GLUT4 translocation through activation of PI3K signaling in skeletal muscle cells. International Journal of Molecular Sciences, 16, 16288-16299. http://dx.doi.org/10.3390/ijms160716288

Valvi, S., Rathod, V., \& Yesane, D. (2011). Screening of three wild edible fruits for their antioxidant Potential. Current Botany, 2(1), 48-52.

\section{Copyrights}

Copyright for this article is retained by the author(s), with first publication rights granted to the journal.

This is an open-access article distributed under the terms and conditions of the Creative Commons Attribution license (http://creativecommons.org/licenses/by/4.0/). 